\title{
Effectiveness of STEM Approach on Mathematical Communication Ability
}

\author{
I Gusti Ngurah Pujawan*, I Putu Pasek Suryawan \\ Mathematic Education Department \\ Universitas Pendidikan Ganesha, Undiksha \\ Singaraja, Indonesia \\ *ngurah.pujawan@undiksha.ac.id,putu.pasek@undiksha.ac.id
}

\begin{abstract}
The idea of integrating Science, Technology, Engineering, and Mathematics in problems brings a new paradigm in teaching and learning mathematics. The innovation to use the STEM learning approach and its daily life applications allowed the students to enhance their mathematical communication skills. The research is aimed at determining the effectiveness of the STEM learning approach on mathematical communication ability. The research used Post-test Only Control Group Design. The study population is all of the third-grade elementary school students of SD Laboratorium Undiksha and SD Mutiara Singaraja in the academic year 2017/2018. The sample of the research was selected using a total sampling technique. The member of the samples is 98 students. The data of student's mathematical communication ability is obtained through a description test. The t-test with a 5\% significance level is used for analysing the data. The result of t-test is tcount $\mathbf{= 7 . 2 7 8}$ and t-table $=1.997$, so tcount $>$ ttable. It means that students' mathematical communication ability who followed the learning with learning STEM approach is higher than students' mathematical communication ability who followed thematic learning. Hence, it can be concluded that the STEM learning approach effectively improved student's mathematical communication ability.
\end{abstract}

Keywords-STEM approach, thematic learning, mathematical communication ability

\section{INTRODUCTION}

Mastering Science and Technology is important to encounter challenges in the future. The challenges that arise include improving the quality of life, the equity of development, and developing human resources. For that, science education as a part of education plays an important role in preparing students to be scientifically literate who can think critically, creatively, logically, and initiatively respond to issues in society caused by the impact of science development and technology. A person's literacy in science is closely related to technological and mathematical literacy [1].

Mathematics is one of the subjects studied in school. According to the Law of the Republic of Indonesia, Number 20 the Year 2003 article 37 on the National Education System, the curriculum of elementary and secondary education shall contain one of the mathematics subjects. Mathematics is fundamental to learn because science and technology will not develop without mathematics [2]. The application of mathematical knowledge can be used as a problem solver in daily life. The main purpose of learning mathematics, as expressed in the Regulation of Minister of National Education Number. 22/2006 about Standard Content of Elementary and Intermediate Education, are: (1) Understanding mathematical concepts, explaining the interconnection between concepts and applying concepts or algorithms in a flexible, accurate, efficient, and precise in problem-solving; (2) Using reasoning on patterns and traits, performing mathematical manipulations in generalizing, compiling evidence or explaining mathematical ideas and statements; (3) Applying problem solving that includes the ability to understand problems, design mathematical models, complete models and interpret the solutions obtained; (4) Communicating ideas with symbols, tables, diagrams, or other media to clarify circumstances or problems; and (5) Having an appreciation of the usefulness of mathematics in life that has a curiosity, attention, and interest in learning mathematics and resilient attitude and confidence in problem-solving.

Sani [3] stated that the student could understand the learning materials effectively if the lesson is applied as follows:

- Integration is learning will be effective if the student integrates knowledge or skills acquired in everyday life.

- Activity is learning will be effective if the student activates their previous knowledge.

- Application is learning will be effective if the student applies knowledge or skills acquired.

- Demonstration is learning will be effective if the student sees demonstrations to be learned.

- Need-base is learning will be effective if the student needs knowledge and skills in doing their work.

Generally, teachers in schools are still dominant in teaching the subject matter in the form of explanations and narratives verbally without meaning. Teachers rarely use instructional media and technology when learning, and teachers sometimes 
do not provide information about the benefits and application of learning materials that are studied so that students tend as listeners, recorders, memorized formulas are given, lack of attention and motivation in learning, and students less actively involved in learning.

Hanifah [4] also expressed a similar condition: students are less active in learning if they only know the teacher's explanation and the recommended package. The students do not really understand the concept of the materials.. This causes a lack of students' mathematical communication skills because students who are not familiar with the taught matter concept can't communicate their mathematical ideas, verbal or written.. Hence, it is necessary to develop a learning innovation that improves students' mathematical communication skills. Siekmann and Korbel [5] stated one approach that can be applied in learning mathematics is the learning STEM approach (Science, Technology, Engineering, and Mathematics).

STEM was firstly introduced by the US National Science Foundation as a theme of educational reform to improve students in understanding STEM [6]. The STEM approach in learning integrates of the field of knowledge in STEM with its application focuses on the learning process of problem-solving in daily life. STEM learning integrates four disciplines [7]: science, technology, engineering and mathematics. Each of the fields can be explained as follow.

Science is a study of nature, including natural laws related to physics, chemistry, biology, and the treatment or application of facts, principles, concepts, or conventions dealing with disciplines. Science is both a body of knowledge accumulated over time and scientific processes of inquiry that generate new knowledge. Knowledge of science informs the design process engineering.

Technology is the knowledge, processes, and devices that enter in creating and operating technology. Throughout history, humans have created technology to meet their wants and needs. Many modern technologies are products of Science, Engineering, and Mathematics.

Engineering is a knowledge-about the design and creation of human-made products and processes to solve problems. Engineering uses concepts in Science, Mathematics, and Technology tools.

Mathematics is the study of patterns and relationships between sum, numbers, and spaces. The conceptual categories of Mathematics include numbers and arithmetic, algebra, functions, geometry, statistics, and probabilities. Mathematics is used in Science, Technology, and Engineering.

Furthermore, the common steps used in STEM learning approaches are:

- Setting the Stage. In this step, the teacher opens the lesson by giving a text or picture of the events occurring in real life related to natural science or technology then the teacher relates to the mathematical material to be studied.

- Exploration. In this step the teacher guides and drives the students in discussions (can be in a group setting) and activities to create designs or products that implement the lesson materials. It can be done by providing cross-questions in designing/product and giving students the freedom to create a design or product. The teacher shows how to use computer programs or employ-learning media to explore mathematical concepts and solve problems.

- Key Concept. In this step, the teacher gives the questions to help the students learn and pay attention to the important parts and get the basic ideas of the subject matter and then record them.

- Practice and Application. $\mathrm{n}$ this step, the teacher provides problems or opportunities to understand the students' related materials [8].

STEM approach in learning is applied together with active learning principal and problem-solving based so that students are taught to think critically, analytically, and focus on solutions [9]. In real life, the STEM approach's application also brings great benefits to the development of science and technology and the development of the students' social skills. In addition, the STEM approach also focuses on engineering and mathematics. In the engineering component, the STEM approach provides solutions and focuses on the process and design [10].

STEM approach in learning is applied together with active learning principal and problem-solving based so that students are taught to think critically, analytically, collaboratively, and focus on finding solutions to a problem [11]. In real life, the application of the STEM approach also brings great benefits to the development of science and technology and the development of the students' social skills, especially in communication and collaboration work. The STEM approach also focuses on engineering and mathematics. $n$ the engineering component, the STEM approach is not only for final solutions but also on the process and design [12].

There are several preliminary studies about the STEM learning approach. Among others, Becker and Kyungsuk research in the research results showed that STEM approach has a positive effect to optimize students' achievement [13]. Mayasari, et al [14] also showed that STEM integrated learning approach has a positive effect on students' learning outcomes. In addition, Ismayani [15] stated that the application of STEM learning positively affect the attitude of students' mathematical creativity.

Inspite of a number of studies about STEM, there is no research addressed the impact of STEM toward students' mathematical communication ability. It is critical because as is explained previously, many students cannot express their idea verbally or written, when it comes to solving a mathematical 
problem. Through STEM approach, the students are expected to improve their mathematical communication skills. Therefore the present study is presented in the title of "Effectiveness of STEM Approach on Mathematical Communication Ability".

\section{Methods}

The study population is all of the third-grade elementary school students of SD Laboratorium Undiksha and SD Mutiara Singaraja in the academic year 2017/2018. 59 students of SD Lab Undiksha are grouped into two classes, and 39 students of SD Mutiara Singaraja are grouped into two classes. Hence, the total number of the population is 98 students. Generally speaking, both schools are relatively equal in terms of facilitates, resources, curriculum (National Curriculum of 2013), and the learning process method.

From that, the sample was selected. Sampling is the process of selecting samples from the population under study, so that the selected sample can represent and describe the nature or characteristics of the actual population [16]. Before sampling, an equality test using t-test was performed to examine the equivalent condition of 2 sample groups [17]. The data used in this equality test is the final mathematics result of the odd semester of the academic year 2017/2018 class of the thirdgrade students of SD Laboratorium Undiksha and SD Mutiara Singaraja.

After obtaining the equivalent sample groups, sampling was taken. The samples were chosen by using a total sampling technique. Total sampling is a sampling technique where the sample equals the population [18]. The reason for taking the total sampling because according to Sugiyono if the population has a number less than 100, the sample is all of them [19].

The sample taken from this research is 98 people. They were grouped into two classes and received different treatment. In each school, a control and experimental group had been assigned.

The A class is called the experimental group, received treatment with STEM learning approach. On the other hand, the B class is called the control group and received treatment with a thematic learning approach.

It is guaranteed that the control groups in SD Lab Undiksha and SD Mutiara Singaraja were following the same learning method using Thematics Approach. Meanwhile the experimental groups in SD Lab Undiksha and SD Mutiara Singaraja were following the same learning method using STEM Approach.

The independent variable in this research is the approches assigned for each class. While the dependent variable in this research is students' mathematical communication ability. The indicators used to determine students' mathematical communication skills are as follow.

- The ability to express mathematical ideas verbal and written, including creating the visualization of it.
- The ability to understand, interpret and evaluate mathematical ideas in verbal, written or visual.

- The ability to use terms, mathematical notations and structures to present ideas that illustrates the relation within situational models.

The design used in this research is Post-test Only Control Group Design. The instrument used to measure students' mathematical communication ability in this research is using description test. It is used to examine the students' comprehension in representing their ideas understanding in words. Before it is applied, the validity and the reliability of the test was examined.

The validity of the test was performed by expert validation. Two experts in mathematics education and assessment examined whether the designed test is relevant or not. The result was analyzed using product-moment correlation coefficient from Carl Pearson. Then, the reliability of valid items were tested by using Alpha Cronbach formula.

After got a valid and reliable instrument, we used it to assess the students' mathematical communication ability. The results was use to analyzed the hypothesis of the research. Before that, we tested its normality and homogeneity. To test the normality of data Lilliefors Test was used, whereas to test the homogeneity of variance F-Test was used [20].

If the data proved to be normally distributed and homogeneous in its variance, then the research's hypothesis can be examined using t-test with $5 \%$ significant level.

In the next data analysis process, the control groups in each school were combined and the experimental groups.

\section{RESULT AND DISCUSSION}

A summary of the data gathered from two sample groups can be seen in Figure 1.

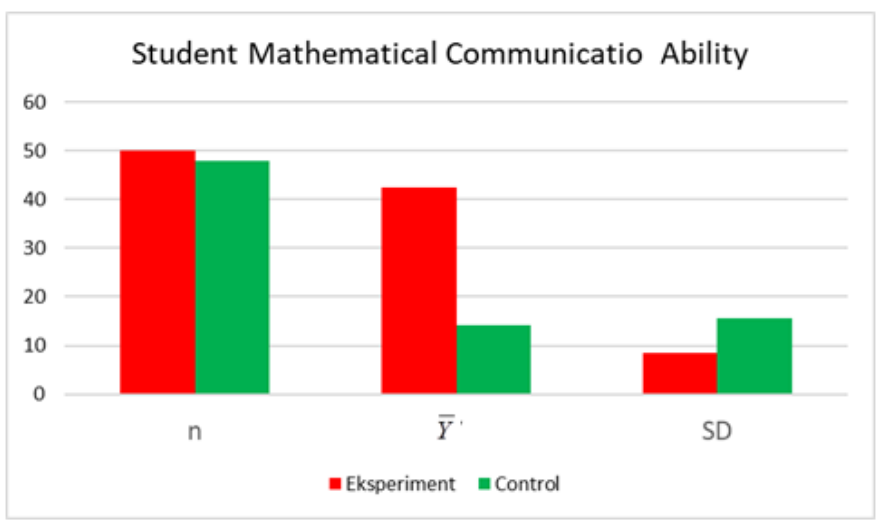

Fig. 1. Results of students mathematical communication ability.

The result of the communication skill in the experimental class is Lcount $=0.1742$ which is less than Ltable $=0.224$ (for $n$ $=50$ at $5 \%$ significance level). Hence, $\mathrm{H} 0$ is accepted. It means 
the mathematical communication score of experimental group is derived from population that is normally distributed.

In the control group, it is obtained that Lcount $=0.1632<$ Ltable $=0.231$ (for $\mathrm{n}=48$ at the $5 \%$ significance level). Hence, $\mathrm{H} 0$ is accepted. It means the mathematical communication score of control group is also derived from the normally population that is normally distributed.

The homogeneity test of variance is done by F-Test. Based on the calculation, it is obtained that the value of $F_{\text {count }}$ $=1.466$ and $F_{\text {table }}=1.79$. Means, $F_{\text {count }}<F_{\text {table. }}$ Thus $H_{0}$ is accepted and it means variance of data is homogen.

Since the data is normal and its variance is homgen, the hypothesis is tested using one-tailed t-test. The summary of the results of the data is presented in Table 1.

\section{TABLE I. T-TEST}

\begin{tabular}{|l|c|c|c|c|c|c|}
\hline \multicolumn{1}{|c|}{ Group } & $\boldsymbol{n}$ & $\overline{\mathbf{y}}$ & $\boldsymbol{s} \mathbf{2}$ & $\boldsymbol{s}^{\mathbf{2}}$ com & \multicolumn{1}{|c|}{$\boldsymbol{t}_{\text {count }}$} & \multicolumn{1}{|c|}{ table } \\
\hline Experiment & 50 & 41.743 & 65.848 & \multirow{2}{*}{80.732} & 7.278 & \multirow{2}{*}{1.997} \\
\hline Control & 48 & 25.875 & 96.545 & & & \\
\hline
\end{tabular}

Based on Table 1, it can be seen that $t_{\text {count }}=7.278$ and. $t_{\text {table }}$ $=1.997$. Therefore $t_{\text {count }}>t_{\text {table }}$ then $H_{0}$ is rejected and $H_{1}$ is accepted. It means, the mathematical communication ability of $3^{\text {rd }}$ grade students of SD Laboratorium Undiksha and SD Mutiara Singaraja taught by STEM learning approach is better than by thematic learning. Hence, it can be generalized that STEAM learning approach has a positive impact towards students' mathematical communication skills. By that, it is expected that students' learning outcome will also be improved.

Moreover, in the experimental class, learning is done through group discussion. It required students to be more active so as to improve their reasoning abilities. In learning using STEM approach with cooperative learning model, the students were encouraged to learn more actively.

Learning mathematics with STEM approach begins with Setting the learning condition. After forming the cooperative group, the teacher gave students' worksheets and showed a story or picture about events that happened in real life related to science or technology. The teacher connected its content with mathematical materials that will be discussed on the day. The aim of the stage is to attract the students to observe the material to be discussed and to motivated them to understand the importance of this material with other knowledge and its application in real life.

The process is continued by the Exploration stage. Here, the students were discussing the given worksheet with their groups. They also discussed the design or product using the materials provided by teacher, related to the subject matter. The teacher guided and directed the student in completing the worksheet and project by giving some leading to inspire them. The teacher also showed how to use instructional media to enhance the students' attention and also improve their understanding to the lesson. Exploration activities aimed to improve the students' ability in applying concepts, facts, procedures and mathematical reasoning.

In the next step called Key Concept, the teacher gave questions that help the students to learn and pay attention to the important basic ideas and the students made the conclusion of it. The questions are intended to enable students to know and understand the concept of the matter taught and its application in life.

The last stage of learning is called Practice and Application. It allowed the students to practice the ability and concepts to explore and apply them to solve various problems. The activity is aimed to enable students to play an active role to solve existing mathematical problems. In relation to student's mathematical communication skills, during this stage, the students have the opportunity to express and reflect their thoughts verbally and written or using visualization. The advantages of each of these stages are that make learning with STEM approach can improve student's mathematical communication ability.

Differently, the activity in thematic learning for control group, is still dominated by teacher. The teacher gave worksheet for the students and it has to be done individually or in groups. The teacher's role is to clarify the students' misconception and mistakes during their works. In the end of the lesson, the teacher gives the individual mini-test.

During the lesson, the observer noticed that during worksheet completion, not all students understood the material nor active to work. It is probably caused by the lack of activities that helps them to express their ideas. Also, there was no explanation and presentation of the application of mathematical material to real life. Therefore, the students' mathematical communication ability is less improved.

The aforementioned explanation showed that teachers' efficacy beliefs and the value they place on STEM education seems to influence their willingness to engage and implement STEM curriculum. This also be supported by Margot and Kettler [21] who stated that the teachers' mastery in certain topic is influencing the students' learning process. The teachers who have limited knowledge and not comfortable with STEM related problems, may feel unpleasant to conduct a lesson using STEM themes.

These findings are consistent with the results of research conducted by Leon et al. [22] which stated that when the students are motivated to actively involved in learning, they will motivate and able to achieve a high scores in mathematics lessons. Similarly, Becker \& Kyungsuk [13] and Mayasari et al [14] and emphasized that STEM approach has a positive effect on learning outcomes. Furthermore, it is also known to affect the students' mathematical creativity [15].

Moreover, it is known that there are other factors that influence the success of STEM learning approach implementation [23]. First, the teacher. To enable teacher in preparing learning materials using STEM approach, it is important to give them support. One type of needed support is 
conducting a professional development for the teacher which can help the teacher understand how to enhance the quality of lesson and assessment techniques in the classroom [24].

From the results, it is found that the application of STEM approach in learning (1) attracted the student's attention to actively observe the discussed materials and to motivate the students by relating it to other knowledge and its application to everyday life, (2) improved the students' skills in applying mathematical concepts, facts, procedures and reasoning, (3) helped the students to know and understand important concepts in learning matter and its application in daily life, and (4) enabled the students to improve their mathematical communication skills since they have the opportunity to express and reflect their thoughts.

\section{CONCLUSION}

Based on the result and discussion, it can be concluded that the mathematical communication ability of the 3th grade students of SD Laboratoium Undiksha and SD Mutiara Singaraja taught with STEM approach is higher than with thematic learning. Hence, STEM approach gives positive influence to students' mathematical communication ability.

We recommend the following points related to our findings.

- The prospective researchers are suggested to test the impact of STEM approaches on different aspects of learning, such as students' achievement.

- The prospective researchers are suggested to conduct the study related to the STEM approach in the broader population and subject matters.

- Educational practitioners, especially the parties involved in learning mathematics, are recommended to apply the STEM approach as one alternative to improve the students' mathematical communication ability.

\section{ACKNOWLEDGMENTS}

The authors would like to appreciate the crucial role of the school principal of SD Laboratorium Undiksha and SD Mutiara Singaraja who gave the permission to do research at schools, and especially to the third grade students and teachers who to help the study. The authors also thanks to all parties who have helped until the completion of the script of this article.

\section{REFERENCES}

[1] OECD, PISA 2015 Assessment and Analytical Framework: Science, Reading, Mathematic and Financial Literacy. Paris: OECD Publishing, 2016
[2] E. Suherman, Strategi Pembelajaran Matematika Kontemporer. Bandung: Universitas Pendidikan Indonesia, 2003.

[3] R. A. Sani, Inovasi Pembelajaran. Jakarta: PT Bumi Aksara, 2014.

[4] Hanifah, "Pengaruh Pendekatan Saintifik terahadap Keterampilan Proses Sains dan Hasil Belajar Kognitif Siswa Kelas VII SMP Negeri 2 Berbah," 2016.

[5] G. Siekmann and P. Korbel, Defining 'STEM' Skills: Review and Synthesis of the Literature. Australia: NCVER, 2016.

[6] Hanover Research, "K-12 STEM education overview," 2011.

[7] National Academy of Sciences, STEM Integration in K-12 Education. Washinton: National Academies Press, 2014.

[8] R. Billstein and J. Williamson, Math Thematics the STEM Project. Evanston: McDougal Littell Inc, 1999

[9] H. Firman, "Pendidikan Sains Berbasis STEM," 2015.

[10] Asmuniv, "Pendekatan Terpadu Pendidikan STEM Upaya Mempersiapkan Sumber Daya Manusia Indonesia yang Memiliki Pengetahuan Interdisipliner dalam Menyosong Kebutuhan Bidang Karir Pekerjaan Masyarakat Ekonomi ASEAN (MEA)," 2015.

[11] California Departement of Education, "Science, Technology, Engineering, and Mathematics," 2015. .

[12] RMC Research Corporation, "Science, Technology, Engineering, Mathematics (STEM) Catalyzing Change Amid the Confusion," 2012. .

[13] K. Becker and P. Kyungsuk, "Effects of Integrative Approaches Among Science, Technology, Engineering, and Mathematics (STEM) Subjects on Students' Learning: A Preliminary Meta-Analysis," J. STEM Educ., vol. 12 , no. 5 , p. $6,2011$.

[14] T. et. al. Mayasari, "Pengaruh Pembelajaran Terintegrasi Science, Technology, Engineering , and Mathematics (STEM) pada Hasil Belajar Peserta Didik: Studi Meta Analisis," 2014. .

[15] A. Ismayani, "Pengaruh Penerapan STEM Project-Based Learning terhadap Kreativitas Matematika Siswa SMK,” Indones. Digit. J. Math. Educ., vol. 3, no. 4, pp. 264-272, 2016.

[16] J. Noor, Metodologi Penelitian: Skripsi, Tesis, Disertasi, dan Karya Ilmiah. Jakarta: Prenadamedia Group, 2011.

[17] I.M. Candiasa, Pengujian Instrumen Penelitian Disertai Aplikasi ITEMAN dan BIGSTEPS. Singaraja: Universitas Pendidikan Ganesha, 2010

[18] S. Suryabrata, Metodologi Penelitian. Jakarta: PT Raja Grafindo Persada, 2006.

[19] Sugiyono, Metode Penelitian Pendidikan. Bandung: Penerbit Alfabeta, 2010

[20] N.L.P. Suciptawati, Metode Statistika Nonparametrik. Denpasar: Udayana University Press, 2009.

[21] K.C. Margot and T. Kettler, "Teachers' perception of STEM integration and education: a systematic literature review," Int. J. STEM Educ., vol. 6 , no. 2, pp. 1-16, 2019.

[22] J. León, J.L. Núñez and J. Liew, "Self-determination and STEM education: Effects of autonomy, motivation, and self-regulated learning on high school math achievement," Elsevier Inc, vol. 43, pp. 156-163, 2015

[23] L.M. Hansen, "Examining ways to meaningfully support students in STEM,” Int. J. STEM Educ., 2018.

[24] M.K. Al Salami, C.J. Makela, and M.A. de Miranda, "Assessing changes in teachers' attitudes toward interdisciplinary STEM teaching," Int. J. Technol. Des. Educ., vol. 27, pp. 63-88, 2017. 